Warm up

\title{
Mens corpora e mens sano
}

\section{P McCrory}

nterested in a Faustian bargain? Some recent research tells us how to

improve brain performance, feel better and live for 500 years while doing some healthy exercise to boot. Mind you there is a downside-you have to give up most foods, exercise like an Olympian, take supplements, and put up with bad breath and flatulence. Oh, and you have to get neutered as well. I knew there was a catch somewhere!

Although many athletes seem overly keen to take creatine as an ergogenic supplement, it may surprise you to learn that it also improves short term memory and reasoning ability. ${ }^{1}$ Strangely enough this effect is only seen in vegetarians. Meat eaters clearly have already optimised their cognitive performance by their choice of diet. The downside of such enthusiastic creatine supplementation is halitosis, flatulence and water retention. Many of these valuable side effects are thought to improve football performance by distracting opponents; however, they can hardly be described as social graces-not that that usually bothers most footballers of my acquaintance.

Exercise in its own right also can improve thinking. Most of us seem to believe this anecdotally; however, an enterprising scientist from the US has just published a critical review in this field demonstrating that concentration, information processing, decision making and reaction times were all improved by aerobic exercise. ${ }^{2}$ The longer the bout of exercise, the better the response. So keep moving is the message-in fact don't stop and you may be as clever as Albert Einstein.

Now that we all realise that exercise improves your brain function and diminishes your social prospects, let me turn to the other point, namely eternal life. In a recent paper from Science, researchers reportedly extended the lifespan of transgenic roundworms to the human equivalent of 500 years without compromising their health. ${ }^{3}$ It turns out that in most life forms, insulin like growth factor 1 (IGF-1), plays a central role in both growth and longevity. An excess of IGF-1 shortens your life span. This is a point that many elite athletes may want to ponder as they inject either IGF-1 or its precursor, growth hormone, into their bodies. Tweaking the roundworm's genes was one aspect of this line of study but excising the germ line cells (i.e. neutering the critter) was the critical step extending the lifespan by approximately $60 \%$.

So there you have it - longevity, vegetarian food, impressive brainpower, aerobic fitness, halitosis, flatulence, no friends and no sex. The 500 year lifespan just seems like eternity.

Br J Sports Med 2003;37:471

\section{REFERENCES}

1 Rae C, Digney AL, McEwan SR, et al. Oral creatine monohydrate supplementation improves brain performance: a double-blind, placebocontrolled, cross-over trial. Proc $R$ Soc Lond B Biol Sci 2003;270(1529):2147-50.

2 Tomporowski PD. Effects of acute bouts of exercise on cognition. Acta Psychol (Amst) 2003;112(3):297-324.

3 Arantes-Oliveira N, Berman JR, Kenyon C. Healthy animals with extreme longevity. Science 2003;302(5645):611. 


\section{Expression of concern about content of which Dr Paul McCrory is a single author}

This paper is authored by Dr Paul McCrory. During 2021 and 2022 there was an investigation by BJSM and BMJ which found that some of his work was the product of publication misconduct. Such misconduct includes plagiarism, duplicate publication, misquotation and misrepresentation in publications in respect of which he was listed as the sole author. ${ }^{1}$ We are placing a notice to readers on all content in relation to which he is identified as the sole author to alert them to the conclusions of our investigation.

(C) Author(s) (or their employer(s)) 2022. No commercial re-use. See rights and permissions. Published by BMJ.

Br J Sports Med 2022;0:1. doi:10.1136/bjsports-2022-106408eoc

D) Check for updates

\section{REFERENCE}

1 Macdonald H, Ragavooloo S, Abbasi K. Update into the investigation of former BJSM editor-in-chief Paul McCrory. Br I Sports Med 2022. 